\title{
GMR
}

\section{New sources of resistance to leafminers (Liriomyza sativae) in melon (Cucumis melo L.) germplasm}

E.F. Celin ${ }^{1}$, F.I.C. Oliveira ${ }^{1}$, N.S. Dias-Pini ${ }^{1,2}$, G.H.S. Nunes ${ }^{3}$ and

F.A.S. Aragã $0^{1,2}$

${ }^{1}$ Departamento de Fitotecnia, Universidade Federal do Ceará, Fortaleza, CE, Brasil

${ }^{2}$ Laboratório de Melhoramento e Recursos Genéticos Vegetais, Embrapa Agroindústria Tropical, Fortaleza, CE, Brasil

${ }^{3}$ Departamento de Ciências Vegetais, Universidade Federal Rural do Semi-Árido, Mossoró, RN, Brasil

Corresponding author: F.A.S. Aragão

E-mail: fernando.aragao@embrapa.br

Genet. Mol. Res. 16 (2): gmr16029561

Received December 1, 2016

Accepted March 3, 2017

Published April 5, 2017

DOI http://dx.doi.org/10.4238/gmr16029561

Copyright $(2017$ The Authors. This is an open-access article distributed under the terms of the Creative Commons Attribution ShareAlike (CC BY-SA) 4.0 License.

\begin{abstract}
Leafminers (Liriomyza sativae) are the main melon (Cucumis melo L.) pests in Northeast Brazil, which is the main region for the production and export of the fruit in Brazil. Of the integrated management strategies available, genetic resistance is the best method of preventing damage by these insects. The aim of this study was to select sources of resistance to leafminers in melon germplasm. Seven experiments were conducted in the laboratory, field, and greenhouse, with and without choice, using 52 melon accessions and 4 commercial hybrids as controls. Genetic variability among the accessions made it possible to select four new sources of resistance: 'CNPH 11-1072' and 'CNPH 11-1077', because they exhibited lower levels of infestation by the insect (antixenosis); and 'CNPH 00-915(R)' and 'BAGMEL
\end{abstract}

Genetics and Molecular Research 16 (2): gmr16029561 
56(R)', because the pest larvae died soon after beginning to feed on the leaf mesophyll (antibiosis).

Key words: Antibiosis; Antixenosis; Genetic variability; Insect resistance

\section{INTRODUCTION}

Melon (Cucumis melo L., $2 \mathrm{n}=2 \mathrm{x}=24$ ) is the most cultivated member of the Cucurbitaceae in the world (Sabato et al., 2015). The socioeconomic importance of the crop depends upon sales of hybrid seeds and fruits, which are mainly consumed in natura. In Brazil, the crop is concentrated in the Northeast region, particularly in the Jaguaribe-Açu agricultural region, because of the favorable climatic conditions. In this region, it is possible to harvest up to three crops a year, and the period of greatest production includes a season for international export, from July to January. These facts make melon the main Brazilian fresh fruit in terms of volume of exports, and the European Union is the main destination (MDIC, 2016).

Despite the success of the crop, pests limit its yield potential, which results in the indiscriminate use of agricultural chemicals and higher production costs, increasing the economic risk of this crop to small farmers. Among melon pests, leafminers in the genus Liriomyza (Diptera, Agromyzidae) have been the main problem. Gallery formation in the leaves, which is caused by larvae that feed on leaf mesophyll, is the main form of damage caused by this pest, and results in reductions in yield and fruit quality (Araújo et al., 2007).

Recently, interest in reducing the costs associated with controlling this insect, losses caused in production, and growing concern about chemical residues in foods and in the environment have encouraged the adoption of integrated pest management (IPM) (Basij et al., 2011). Genetic resistance in plants is a relevant control technique within IPM. This strategy is considered ecologically ideal, it is easily adopted by the producer and can be implemented with other management techniques. Currently, for these reasons, the main objectives of breeding programs have been to introduce cultivars resistant to different types of stressors, whether biotic or abiotic, on the market (Borém and Fritsche-Neto, 2012).

Although there are melon cultivars that have some level of tolerance to leafminers, there are no cultivars that are resistant to this insect. It should be emphasized that tolerance only involves characteristics that are related to the plant, while resistance results from an interaction between the characteristics of the plant and of the insect (Morais and Pinheiro, 2012). In general, resistance can be categorized into two types: i) antixenosis (or non-preference), in which the plant changes insect behavior, resulting in the selection of an alternative host; and ii) antibiosis, in which the plant has a negative effect on the insect's biology (e.g., development and fecundity), and can be sublethal or lethal (Dogimont et al., 2010). In both cases, resistance is relative, and comparisons of genotypes that are under the same experimental conditions are necessary.

The identification of sources of resistance in the germplasm available is a first step in obtaining resistant cultivars. A considerable volume of germplasm is conserved in active germplasm banks (AGBs), which are in Russia ( $>2900$ accessions), the United States $(>2300$ accessions), France (>1800 accessions), China (>1200 accessions), and, in Brazil, in the Melon AGB of Embrapa Hortaliças ( $\sim 400$ accessions) and the Cucurbitaceae AGB of Northeast Brazil ( $\sim 150$ accessions) (Aragão, 2011). Genetic diversity in the germplasm makes it possible for sources that contain favorable alleles to be identified and selected by characterization and evaluation. Nevertheless, few accessions have been characterized or evaluated for the trait of

Genetics and Molecular Research 16 (2): gmr16029561 
resistance to Liriomyza spp, and few promising sources have been identified (Nunes et al., 2013; Dogimont and Boissot, 2016; Oliveira FIC, Fiege LBC, Celin EF, Innecco R, et al., unpublished results). Therefore, the aim of this study was to identify promising sources of resistance to leafminers in melon germplasm.

\section{MATERIAL AND METHODS}

Seven experiments were conducted: three in the laboratory (LAB1, LAB2, and LAB3), one in a greenhouse $(\mathrm{GH})$, and three under field conditions (F13, F14, and F15) (Figure 1). The trial without choice (LAB1) had a completely randomized design (CRD), with six replications. However, trials LAB2, LAB3, and GH (with choice) had a randomized complete block design (RCBD), with three, six, and four replications, respectively. In these trials, each plant constituted a plot. In the field, the experiments were RCBD with two replications. Each plot contained six, eight, and ten plants in 2013 (F13), 2014 (F14), and 2015 (F15), respectively.
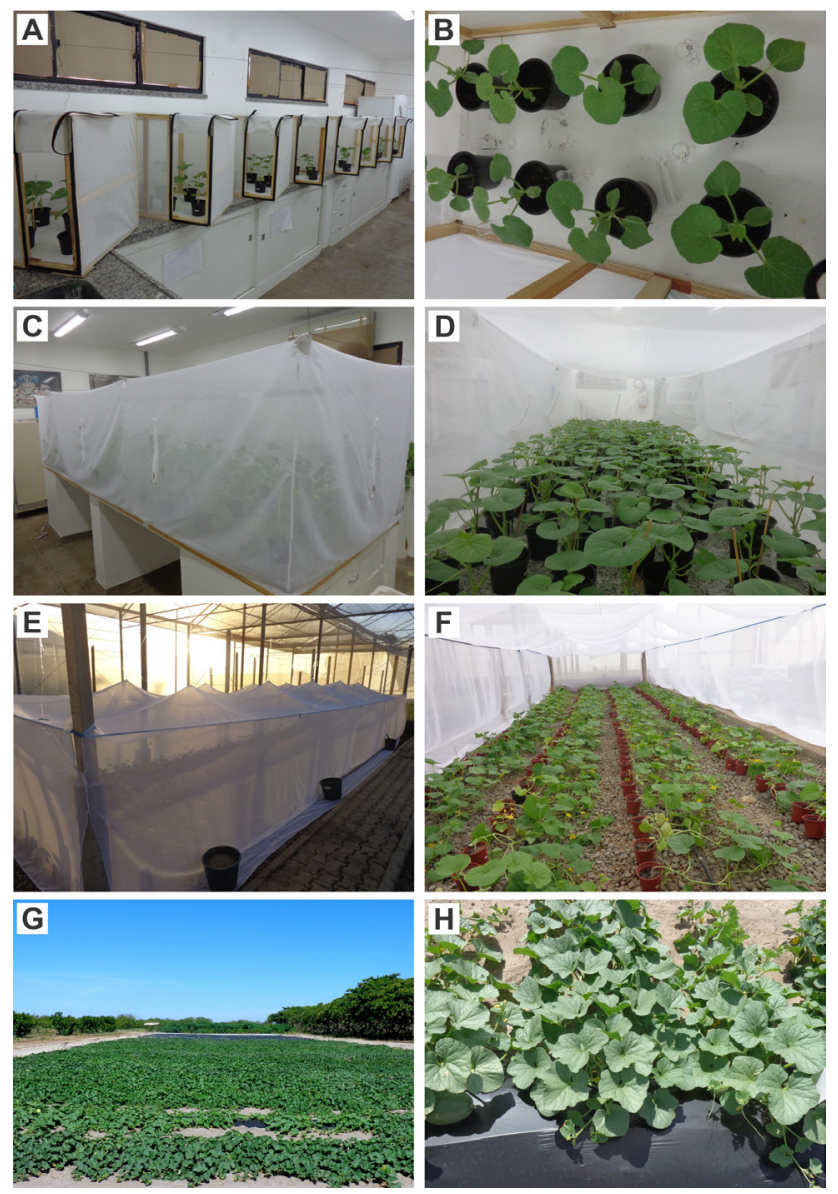

Figure 1. Leafminers resistance evaluation experiments in melon germplasm in: the laboratory without choice (A and B) and with choice (C and $\mathbf{D})$; greenhouse with choice (E and $\mathbf{F})$; and, under field conditions with choice $(\mathbf{G}$ and $\mathbf{H})$. 


\section{Germplasm}

Forty-six melon accessions were obtained from the Melon AGB of Embrapa Hortaliças (Brasília, DF, Brazil), two accessions were obtained from the Cucurbitaceae Germplasm Bank of Northeast Brazil, Embrapa Semiárido (Petrolina, PE, Brazil), and four commercial hybrids ('BRS-Araguaia', 'Iracema', 'Goldex', and 'Olimpic') were included as standards of susceptibility. The study was divided into experiments with young plants under controlled infestation (cages) and with adult plants under natural infestation (field). In both environments, leafminer samples were collected and sent for taxonomic identification by the Agricultural Entomology Laboratory at Universidade Federal Rural de Pernambuco, Recife, PE, Brazil.

\section{Evaluations}

\section{Young plants under controlled infestation}

The trials were conducted in a greenhouse and in the Plant Breeding and Genetic Resources Laboratory of Embrapa Agroindústria Tropical $\left[3^{\circ} 44^{\prime} \mathrm{S}, 38^{\circ} 33^{\prime} \mathrm{W}\right.$ and $19.5 \mathrm{~m}$ above mean sea level (AMSL)], Fortaleza, CE, Brazil. Three trials were conducted in the laboratory, one without choice (July 2013, LAB1) and two with choice (July 2014, LAB2 and October 2014, LAB3), and one in a greenhouse with choice (July 2014, GH). In the tests with choice, the treatments were placed in the same cage so that the insects could choose among the genotypes. In the test without choice, plants of each genotype were in individual cages.

To obtain the plants, seeds were sown in 200-cell polyethylene trays filled with coconut fiber powder. On the 10th day after sowing, the seedlings were transferred to $0.3-\mathrm{L}$ polyethylene pots containing sand and earthworm humus at a proportion of 5:1. The plants remained in the greenhouse from sowing until infestation or evaluation, and nutritional requirements were met through fertigation.

The plants were infested when they had six fully expanded true leaves (26 days after sowing). The plants were transported to the laboratory and placed in cages in which eight flies, with an age of up to $48 \mathrm{~h}$, were released per plant. The insects were reared in the laboratory, and were obtained from periodic collections in the melon production area of the JaguaribeAçu agricultural region and subsequently multiplied on jack bean [Canavalia ensiformis L. (Fabaceae)] to avoid preimaginal conditioning. After $24 \mathrm{~h}$ of infestation, the plants were removed from contact with the adult insects and kept in a greenhouse until evaluation. Four days after infestation, the number of mines per leaf on each young plant (NMLyp) was counted.

\section{Adult plants under natural infestation}

Three trials were conducted in the Experimental Field of Pacajus, CE, Brazil ( $4^{\circ} 10^{\prime} \mathrm{S}$, $38^{\circ} 27^{\prime} \mathrm{W}$ and $60 \mathrm{~m} \mathrm{AMSL}$ ), which belongs to Embrapa Agroindústria Tropical, in three consecutive years: December 2013, October 2014, and November 2015. The seedlings were obtained as described above and transplanted in the field at 10 days after sowing with 2.0 $\mathrm{m}$ between the rows and $0.4 \mathrm{~m}$ between the plants. A drip irrigation system was used, and fertilizer was applied daily through fertigation. No insecticide was used.

In the final phase of the crop cycle (a few days before harvest, 50 days after transplanting), the damage caused by the leafminers was visually evaluated and scored (SSap),

Genetics and Molecular Research 16 (2): gmr16029561 
and the number of mines in the leaves (NMLap) was counted. To score the damage, a scale of 1-5 was used: $1=$ plant without mines in the leaves; $2=1-25 \%$ of the leaves attacked; 3 $=26-50 \%$ of the leaves attacked; $4=51-75 \%$ of the leaves attacked; and $5=76-100 \%$ of the leaves attacked. To ascertain the NMLap, the 10th leaf on the first three secondary branches was collected from four plants per plot, and the number of mines per leaf was counted (Braga Sobrinho et al., 2003). The SSap and NMLap were estimated based on the means for each plot.

\section{Plants with antibiosis}

Melon plants resistant to the leafminer, presumably through antibiosis, were selected, and the type of resistance was evaluated through the progeny. Because selection occurred before flowering, these plants were self-pollinated to obtain their respective progenies, and the progenies were grown from seeding to infestation as described for young plants under controlled infestation. Four days after infestation, the number of mines (NM) per leaf on each plant was counted. Under laboratory conditions, leaves with larvae exhibiting normal development were stored in plastic cups for collection and determination of the number of pupae (NP), and, later, the number of adults (NA). The hybrid 'Goldex' was used as a commercial control. Larval viability per plant $[\mathrm{LV}=100(\mathrm{NP} / \mathrm{NM})]$ was estimated, and plants were grouped into five classes: $1=$ resistant $(0 \% \mathrm{LV}) ; 2=$ moderately resistant $(1-25 \% \mathrm{LV})$; $3=$ intermediate $(26-50 \% \mathrm{LV}) ; 4=$ moderately susceptible $(51-75 \% \mathrm{LV})$; and $5=$ susceptible $(76-100 \%$ LV). Pupal viability $[\mathrm{PV}=100(\mathrm{NA} / \mathrm{NP})]$ and the descriptive statistics of each population were also obtained.

\section{Statistical analyses}

The data were analyzed using mixed models. Predictions of the genetic values were obtained by the best linear unbiased predictor method, and estimates of the components of variance were obtained by the restricted maximum likelihood procedure. Two blocks of experiments, both with choice, were analyzed in a combined form. The first joined the experiments in the field (F13, F14, and F15), in which the traits NMLap and SSap were evaluated, and the second joined the experiments under controlled infestation (LAB2, LAB3, and $\mathrm{GH}$ ), which evaluated the NMLyp trait. The data were analyzed in matrix form, considering the following statistical models (Resende and Duarte, 2007):

$$
y=X r+Z g+W i+e
$$

where $y$ is the vector of the phenotypic means of the data, $r$ is the vector of the effects of replication (assumed as fixed) that is added to the overall mean, $g$ is the vector of genotypic effects (assumed as random), $i$ is the vector of the effects of the genotype $\mathrm{x}$ environment ( $\mathrm{G}$ $\mathrm{x} \mathrm{E}$ ) interaction (random), $e$ is the vector of the errors or residues (random), and $X, Z$, and $W$ are incidence matrices that relate the effects $r, g$, and $i$ to the vector $y$, respectively (combined analysis of the trials):

$$
y=X u+Z g+e
$$

where $y$ is the vector of the phenotypic means of the data, $u$ is the scalar in reference to the

Genetics and Molecular Research 16 (2): gmr16029561 
overall mean (fixed effect), $g$ is the vector of genotypic effects (assumed as random), $e$ is the vector of the errors or residues (random), and $X$ and $Z$ are incidence matrices that relate the effects $r$ and $g$, respectively, to the $y$ vector (trials in CRD):

$$
y=X r+Z g+e
$$

where $y$ is the vector of the phenotypic means of the data, $r$ is the vector of the effects of replication (assumed as fixed) that is added to the overall mean, $g$ is the vector of genotypic effects (assumed as random), $e$ is the vector of the errors or residues (random), and $X$ and $Z$ are incidence matrices that relate the $r$ and $g$ effects, respectively, to the $y$ vector (trials in RCBD). Analyses of deviance were conducted to evaluate the effect of genotype and the interaction, and the likelihood ratio test was used to test the comparisons. For variables that had significant effects, ranking was based on the genotypic values: genotypes with low values and that maintained stability of performance for non-preference by the leafminers were considered superior.

\section{RESULTS AND DISCUSSION}

Taxonomic identification of the insect samples revealed that the only species present was Liriomyza sativae Blanchard 1938 (Diptera, Agromyzidae). Therefore, this is the main pest species in the melon production areas of the Jaguaribe-Açu agricultural region, and corroborates the findings of previous studies (Costa-Lima et al., 2009; Araújo et al., 2013; Ferreira, 2014).

The SSap trait did not exhibit a significant $G \times \mathrm{E}$ interaction, indicating that the responses of the genotypes were similar (Table 1). In addition, a significant effect of genotype and a strong genetic correlation $(75 \%)$ were found among the environments, which allowed the selection of the following accessions to be performed: 'CNPH 00-919', 'CNPH 01-925', 'CNPH 01-963', 'CNPH 06-19157', 'CNPH 11-233', 'CNPH 11-282', 'CNPH 11-1072', 'CNPH 11-1077', 'CNPH 82-0915', 'CNPH 93-691', 'CNPH 94-001', 'CNPH 94-002', and 'CNPH 94-244' (Table 2).

$\chi^{2}\left(\mathrm{Gx}\right.$ E), effect of the gene $\mathrm{x}$ environment interaction on phenotypic variance; $\mathrm{h}_{\mathrm{mg}}{ }^{2}$, mean heritability; $\mathrm{Ac}_{\mathrm{g}}$, selection accuracy; $\mathrm{r}_{\text {gloc }}$, genetic correlation among all environments; $\mathrm{V}_{\text {phen }}$, phenotypic variance; $\mathrm{V}_{\mathrm{gen}}$, genotypic variance; $\mathrm{V}_{\mathrm{e}}$, residual variance; $\mathrm{CV}_{\mathrm{g}}$, coefficient of genetic variation; $\mathrm{CV}_{\mathrm{e}}$, coefficient of residual variation; $\mathrm{CV}_{\mathrm{r}}$, relative coefficient of variation $\left(\mathrm{CV}_{\mathrm{r}}=\mathrm{CV}_{\mathrm{g}} / \mathrm{CV}_{\mathrm{e}}\right)$.

In contrast, for NMLap and NMLyp, there was a significant effect of the $\mathrm{G} \times \mathrm{E}$ interaction and a non-significant effect of genotype (Table 1), indicating that the responses of the genotypes differed. After breaking down the accessions in each environment, a significant effect of genotype was observed (Table 1). This significant effect was diluted when analyzed in a combined manner, suggesting that there was a complex interaction, which was corroborated by the low genetic correlations among the environments (NMLyp $=14 \%$ and NMLap $=$ $24 \%$; Table 1). Therefore, superior accessions that did not vary in their performances in the environments were selected. Only 'CNPH 11-1072' was selected based on NMLyp; and 'CNPH 11-1072', 'CNPH 11-1077', and 'CNPH 94-244' were selected based on NMLap (Table 2).

For NMLyp, which was also evaluated in the experiment without choice (LAB1), there was a significant effect among the treatments (Table 1) that allowed the selection of the

Genetics and Molecular Research 16 (2): gmr16029561 
following genotypes: 'BRS Araguaia', 'CNPH 01-925', 'CNPH 01-963', 'CNPH 03-972', 'CNPH 11-196', 'CNPH 11-282', 'CNPH 11-1067', 'CNPH 11-1072', 'CNPH 11-1077', 'CNPH 82-009', 'CNPH 93-690', 'CNPH 93-691', 'CNPH 94-254', and 'CNPH 98-248' (Table 2).

Table 1. Deviances, variance components, estimated genetic parameters, and means of the number of mines per leaf (NMLap) and subjective score (SSap) in 2013 (F13), 2014 (F14), and 2015 (F15) in adult melon genotypes in the field, and of the number of mines per leaf (NMLyp) in young melon genotypes under controlled infestation with choice in the laboratory (LAB2 and LAB3) and greenhouse (GH) and without choice in the laboratory (LAB1).

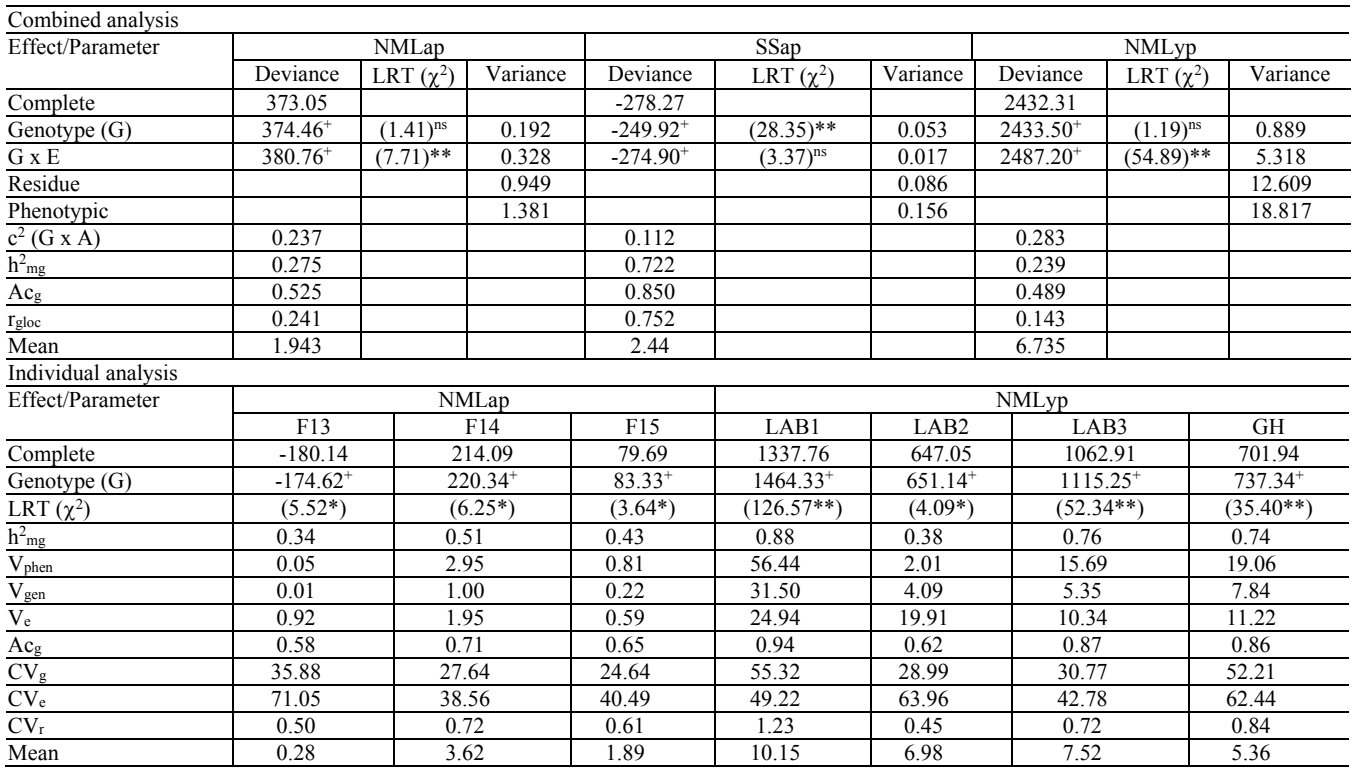

${ }^{+}$Deviance of the adjusted model without the effect referred to; likelihood ratio test (LRT) tested by chi-square with 1 degree of freedom. ${ }^{* *}$ Significant at the $1 \%$ probability level. $*$ Significant at the $5 \%$ probability level. ${ }^{\text {ns }}$ Not significant.

The experiments without choice provide additional information to the experiments with choice, because an accession that performed well among the accessions when they were placed together may be severely attacked when it is the only option as host for the insect. Of the accessions selected, 'CNPH 11-1072' had a similar, resistant response in the two types of experiment. In contrast, 'CNPH 94-244', although considered superior in most of the trials with choice, was classified as susceptible in the experiment without choice, and was among the genotypes that were most attacked. Therefore, considering the variables analyzed the accessions 'CNPH 11-1072' and 'CNPH 11-1077' were selected as antixenosis-type sources of resistance, because both were among the genotypes that were least attacked in all of the experiments. 'CNPH 01-925', 'CNPH 11-282', 'CNPH 93-691', 'CNPH 94-002', and 'CNPH 94-244' also exhibited good performances in most of the trials, and should be included in the next trials (Table 2).

The commercial hybrids were among the genotypes with the highest genotypic values for the trait NMLap, and were among the intermediate accessions for the traits NMLyp and SSap, except for 'BRS Araguaia' for NMLap (F13) and NMLyp (LAB 1). It is noteworthy

Genetics and Molecular Research 16 (2): gmr16029561 
Table 2. Genotypic values $(u+g)$ for the number of mines per leaf (NMLap) and subjective score (SSap) in adult melon genotypes in trials with choice in the field (F13, F14, and F15), and for the number of mines per leaf (NMLyp) in young plants in trials with choice in the laboratory (LAB2 and LAB3) and greenhouse (GH) and without choice in the laboratory (LAB1).

\begin{tabular}{|c|c|c|c|c|c|c|c|c|}
\hline \multirow[t]{2}{*}{ Genotype $^{1}$} & \multicolumn{3}{|c|}{ NMLap } & \multirow{2}{*}{$\begin{array}{l}\text { SSap } \\
\text { Mean }\end{array}$} & \multicolumn{4}{|c|}{ NMLyp } \\
\hline & F13 & F14 & V15 & & LAB1 & LAB2 & LAB3 & $\mathrm{GH}$ \\
\hline CNPH 00-900 & $0.22^{2}$ & 3.56 & 1.57 & 2.33 & 8.21 & 9.61 & 7.33 & - \\
\hline CNPH 00-902 & 0.26 & 3.01 & 1.57 & 2.53 & 11.35 & 9.34 & 6.80 & 7.01 \\
\hline CNPH 00-915 & 0.23 & 2.88 & 1.25 & 2.41 & 12.00 & 7.02 & 5.40 & 6.78 \\
\hline CNPH 00-919 & 0.21 & 3.05 & 1.94 & 2.31 & 7.31 & 7.81 & 8.56 & 5.95 \\
\hline CNPH 01-925 & 0.27 & 3.05 & 1.50 & 2.32 & 6.55 & 6.61 & 7.25 & 3.37 \\
\hline CNPH 01-930 & 0.28 & 3.03 & 1.76 & 2.63 & 10.93 & 8.05 & 10.83 & 4.32 \\
\hline CNPH 01-933 & - & 3.20 & 2.12 & 2.41 & 12.71 & 8.15 & 8.08 & 8.05 \\
\hline CNPH 01-960 & - & 3.56 & 1.73 & 2.63 & 6.83 & 8.02 & - & 9.01 \\
\hline CNPH 01-963 & - & 3.85 & 1.83 & 2.21 & 2.82 & 7.91 & 9.06 & 8.55 \\
\hline CNPH 03-966 & 0.20 & 3.69 & 1.92 & 2.44 & 7.81 & 10.18 & 6.37 & 5.72 \\
\hline CNPH 03-972 & 0.40 & 3.10 & 2.01 & 2.52 & 4.30 & 7.92 & 4.17 & 5.56 \\
\hline CNPH 915-980 & 0.14 & 3.20 & 1.67 & 2.42 & 6.93 & 7.85 & 9.57 & 5.88 \\
\hline CNPH 06-1046 & 0.21 & 2.82 & 2.06 & 2.39 & 7.38 & 8.05 & 8.51 & 6.27 \\
\hline CNPH 06-1047 & 0.17 & 3.71 & 1.52 & 2.15 & 19.34 & 7.27 & 6.58 & 8.96 \\
\hline CNPH 10-1055 & 0.42 & 3.52 & 2.08 & 2.71 & 10.90 & 6.16 & 6.38 & 6.04 \\
\hline CNPH 11-196 & 0.24 & 2.99 & 2.30 & 2.55 & 3.69 & 8.40 & 5.07 & 7.81 \\
\hline CNPH 11-233 & 0.27 & 3.43 & 1.96 & 2.18 & 8.88 & 5.92 & 8.47 & 3.35 \\
\hline CNPH 11-247 & 0.45 & 4.57 & 1.83 & 2.36 & 20.07 & 7.78 & 4.06 & 4.45 \\
\hline CNPH 11-282 & 0.18 & 3.31 & 1.62 & 2.26 & 3.50 & 7.10 & 7.26 & 7.86 \\
\hline CNPH 11-537 & 0.46 & 3.56 & - & 2.41 & 20.56 & 8.26 & 8.49 & - \\
\hline CNPH 11-1059 & 0.32 & 3.58 & 1.89 & 2.36 & 12.45 & 5.18 & 3.99 & - \\
\hline CNPH 11-1061 & 0.35 & 3.01 & 2.22 & 2.7 & 14.73 & 6.81 & 8.30 & 3.58 \\
\hline CNPH 11-1063 & 0.38 & 2.69 & 2.01 & 2.74 & 9.45 & 6.86 & 7.69 & 7.33 \\
\hline CNPH 11-1065 & 0.48 & 3.16 & 2.58 & 2.6 & 17.61 & 6.54 & 5.90 & 13.22 \\
\hline CNPH 11-1066 & 0.30 & 3.66 & 2.67 & 2.74 & 11.70 & 7.32 & 7.69 & 8.02 \\
\hline CNPH 11-1067 & 0.25 & 4.22 & 2.26 & 2.53 & 5.13 & 5.54 & 15.21 & 5.24 \\
\hline CNPH 11-1068 & 0.35 & 4.70 & 1.99 & 2.78 & 18.49 & 5.19 & 5.53 & 6.96 \\
\hline CNPH 11-1069 & 0.33 & 4.36 & 1.78 & 2.44 & 14.52 & 8.27 & 5.67 & 8.14 \\
\hline CNPH 11-1070 & 0.30 & 3.52 & 2.14 & 2.83 & 17.92 & 6.40 & 7.66 & 4.55 \\
\hline CNPH 11-1072 & 0.16 & 2.19 & 1.43 & 1.82 & 5.22 & 4.73 & 4.24 & 2.17 \\
\hline CNPH 11-1074 & 0.38 & 3.47 & 2.37 & 2.57 & 9.50 & 6.65 & 6.81 & 3.16 \\
\hline CNPH 11-1076 & 0.45 & 4.99 & 1.87 & 2.59 & 13.93 & 9.15 & 9.05 & 3.63 \\
\hline CNPH 11-1077 & 0.17 & 2.95 & 1.54 & 2.20 & 5.38 & 5.99 & - & - \\
\hline CNPH 82-004 & 0.22 & 4.09 & - & 2.28 & 17.78 & 7.88 & 8.26 & - \\
\hline CNPH 82-006 & 0.29 & 3.39 & 2.13 & 2.42 & 11.67 & 6.27 & 9.49 & 5.47 \\
\hline CNPH 82-009 & 0.38 & 4.34 & 1.85 & 2.51 & 3.78 & 5.78 & 10.66 & 3.12 \\
\hline CNPH 86-277 & 0.17 & 3.96 & 1.78 & 2.35 & 12.13 & 5.80 & 6.62 & 2.38 \\
\hline CNPH 89-574 & 0.45 & 4.64 & 2.03 & 2.67 & 13.62 & 5.57 & 7.55 & 3.74 \\
\hline CNPH 93-690 & 0.27 & 3.35 & 1.89 & 2.49 & 5.64 & 6.38 & 5.98 & 3.92 \\
\hline CNPH 93-691 & 0.21 & 4.36 & 1.53 & 2.25 & 4.03 & 6.46 & 5.83 & 3.00 \\
\hline CNPH 93-693 & 0.25 & 3.52 & 1.64 & 2.5 & 13.88 & 4.89 & 8.55 & 2.63 \\
\hline CNPH 94-001 & 0.27 & 3.37 & 1.85 & 2.13 & 8.16 & 6.07 & 5.27 & 4.89 \\
\hline CNPH 94-002 & 0.18 & 3.28 & 1.97 & 2.31 & 8.49 & 6.13 & 8.09 & 2.45 \\
\hline CNPH 94-244 & 0.21 & 3.14 & 1.39 & 2.11 & 11.69 & 4.72 & 7.36 & 1.72 \\
\hline CNPH 94-254 & 0.18 & 3.16 & 2.23 & 2.38 & 4.76 & 7.15 & 7.45 & 2.98 \\
\hline CNPH 98-248 & 0.24 & 3.24 & 1.78 & 2.51 & 2.39 & 5.56 & 8.72 & 2.17 \\
\hline BAGMEL 45 & 0.24 & 3.41 & - & 2.33 & 11.71 & 7.54 & 7.62 & 2.52 \\
\hline BAGMEL 56 & 0.34 & 3.60 & 1.53 & 2.46 & 8.92 & 6.42 & 8.55 & 6.64 \\
\hline BRS Araguaia & 0.20 & 4.13 & 2.23 & 2.57 & 4.43 & 7.13 & 8.80 & 8.16 \\
\hline Olimpic & - & 4.45 & 2.13 & 2.51 & - & 7.45 & 7.40 & 5.37 \\
\hline Iracema & - & 6.24 & 1.76 & 2.49 & - & 6.62 & 6.83 & 5.49 \\
\hline Goldex & 0.38 & 5.06 & 2.21 & 2.53 & 22.61 & 6.99 & 10.78 & 4.50 \\
\hline
\end{tabular}

${ }^{1} \mathrm{CNPH}$, obtained from the Embrapa Vegetable Crops active germplasm bank (AGB); BAGMEL, obtained from the Embrapa Semiarid AGB. ${ }^{2}$ Values in bold indicate the best-evaluated accessions.

that, among the controls, 'BRS Araguaia' was the only one that had its parent lines and its own performance evaluated for resistance to leafminers in the Jaguaribe-Açu region. Most of the accessions exhibited differing performances, possibly because of the specific conditions in each environment and the type of characteristic evaluated (Nunes et al., 2013).

Genetics and Molecular Research 16 (2): gmr16029561 
A similar result was obtained in the evaluation of 22 melon accessions in regard to their reactions to Liriomyza spp. because there was also no consistency in their performances in the greenhouse and in the field for two years, except for 'AC-22' (Nunes et al., 2013). Other studies have also reported the selection of only a few melon accessions that are resistant to leafminers, e.g., Kennedy et al. (1978) reported that of 50 accessions, only 'PI 282448' and 'PI 313970' exhibited good resistance to L. sativae, and Dogimont et al. (1995) found that of 110 accessions, only 'Nantais Oblong' exhibited resistance to L. trifolii. In field conditions in the Sudan, where L. sativae is the most common species, only the accession 'HDS 2445' was considered resistant by having the lowest infestation rate of the 100 accessions evaluated (Gesmallah and Yousif, 2004).

In the selection process, it is fundamentally important to verify the precision of the experiments conducted. This precision in selection can be confirmed using genetic parameters, such as heritability and accuracy (Albuquerque et al., 2015). The trait NMLyp in the experiments with controlled infestation had the highest heritability values ( 74 to $88 \%$ ), except for trial LAB2 (38\%). Over the three years of the experiment in the field, the heritability of NMLap varied between 34 and 51\%, and that of SSap was 72\% (Table 1). In general, for these traits, a considerable fraction of the phenotypic variance was due to genetic effects, which would result in the selection of superior genotypes.

The variables were evaluated with a moderate to high accuracy (Table 1), according to Resende and Duarte (2007). High accuracy results in highly reliable genotypic value predictions, and the selection of the best accessions (Albuquerque et al., 2015). Selection accuracy has been used to make inferences in regard to precision, because it is related to the relative coefficient of variation and the number of replications (Resende and Duarte, 2007). Therefore, in this work, the estimate of parameters ensured the superiority of the genotypes selected ('CNPH 11-1072' and 'CNPH 11-1077').

\section{Antibiosis type sources of resistance}

Two plants were selected in the trials LAB2 and F14, one plant of accession ' $\mathrm{CNPH}$ 00-915' and one of 'BAGMEL 56', respectively. These plants were denominated 'CNPH 00 915(R)' and 'BAGMEL 56(R)' because they exhibited possible antibiosis-type resistance to $L$. sativae. The pest larvae died after they began feeding on the leaf mesophyll of these genotypes, and, consequently, they had mines that were smaller than $1 \mathrm{~cm}$.

In both cases, only one plant stood out among the other replications of the accession, suggesting that these accessions are composed of more than one genotype. This may have been a result of the manner of collection, because most of the accessions were obtained in the field and would have had large genetic variability due to the mixed reproductive system of the melon. Having more than one genotype in an accession can also occur by seed mixing, natural crosses, and mutations (Borém and Miranda, 2013). In addition, it may not be the case that the antibiosis-type resistance observed in the selected plants was caused by genetic defense mechanisms, because plants can erroneously be characterized as resistant by exhibiting pseudo-resistance, through escape, induction, phenotypic mismatch, or other non-hereditary factors (Gallo et al., 2002). However, this uncertainty was discarded upon evaluation of the first generation of self-pollinated plants of 'CNPH 00-915(R)' and 'BAGMEL 56(R)' (Table $3)$. The progenies obtained, 'CNPH 00-915' $\left(\mathrm{S}_{1}\right)$ and 'BAGMEL 56' $\left(\mathrm{S}_{1}\right)$, were evaluated under controlled infestation in October 2014 and February 2015, respectively.

Genetics and Molecular Research 16 (2): gmr16029561 
Table 3. Larval and pupal viability of Liriomyza sativae on the melon progenies ' $\mathrm{CNPH} 00-915$ ' $\left(\mathrm{S}_{1}\right)$ and 'BAGMEL 56' ( $\left.\mathrm{S}_{1}\right)$, and 'Goldex' (control).

\begin{tabular}{l|c|c|c|c|c|c|c|c}
\hline \multirow{2}{*}{ Progeny } & \multicolumn{9}{|c|}{ Larval viability (\%) } & \multirow{2}{*}{ LV Mean } & \multirow{2}{*}{ PV Mean } & \multirow{2}{*}{ Number of plants } \\
\cline { 2 - 10 } & 0 & $1-25$ & $26-50$ & $51-75$ & $76-100$ & & & \\
\hline CNPH 00-915 $\left(\mathrm{S}_{1}\right)$ & 19 & 4 & 3 & 3 & 9 & 38.80 & 80.28 & 38 \\
\hline BAGMEL 56 $\left(\mathrm{S}_{1}\right)$ & 31 & 0 & 1 & 4 & 4 & 26.02 & 81.88 & 40 \\
\hline Goldex & 0 & 0 & 0 & 4 & 11 & 84.59 & 75.08 & 15 \\
\hline
\end{tabular}

LV, larval viability; PV, pupal viability.

There was segregation in the two self-pollinating populations, 'CNPH 00-915' $\left(\mathrm{S}_{1}\right)$ and 'BAGMEL-56' $\left(\mathrm{S}_{1}\right)$. Plants grouped in the first class exhibited a similar performance to the parent plants, i.e., they exhibited lethal antibiosis $(0 \%$ of LV), which confirmed the hereditary nature of the resistance. Therefore, the antibiosis resistance of the parents was maintained by the progenies and was caused by genetic defense mechanisms.

Lethal antibiosis to Liriomyza sativae larvae in melon has been reported in three other genotypes. The accessions 'PI 282448' (Africa) and 'PI 313970' (India), which were selected because they have few mines and high $L$. sativae larval mortality, exhibit apparent recessive resistance and incomplete dominance, respectively (Kennedy et al., 1978). In 'Nantais Oblong' (France), the same phenotype was observed in regard to L. trifolii (Dogimont et al., 1995), and resistance in this line is controlled by one gene with complete dominance (Dogimont et al., 1999; Dogimont, 2011). Although these sources were described more than 20 years ago, there have been no subsequent reports of introgression in commercial cultivars, and the plant defense mechanisms responsible for larval mortality have also not been described (Dogimont and Boissot, 2016).

It is noteworthy that the plants selected in this study were not homozygous for the trait in question, which was verified by the segregation in the $\mathrm{S}_{1}$ generation (Table 3 ). In the progeny 'CNPH 00-915' $\left(\mathrm{S}_{1}\right)$, half of the plants exhibited antibiosis that was lethal to the larvae ( $\mathrm{LV}=$ $0 \%$ ), and, in the others, $\mathrm{LV}$ ranged from 3 to $100 \%$. In the 'BAGMEL 56 ' $\left(\mathrm{S}_{1}\right)$ progenies, more than $70 \%$ had the same response as the parent $(\mathrm{LV}=0 \%)$, and in the others, the $\mathrm{LV}$ ranged from 47 to $100 \%$. The LV in 'Goldex' ranged from 63 to $100 \%$. This allowed contrasting lines (resistant and susceptible) to be obtained from the two segregating populations.

The low mean value of LV observed in the two $\mathrm{S}_{1}$ populations in relation to 'Goldex' was mainly caused by plants that did not allow larval development (Table 3). In contrast, in relation to the mean PV, the $\mathrm{S}_{1}$ populations had values near to those of 'Goldex'. The 'Goldex' PV could have been higher if the plants had been less infested. There was probably competition among the larvae for food, because plants of the commercial genotype were highly infested. Competition for food may have led to abnormal formation of the pupae, which prevented them from reaching adulthood. In the two $S_{1}$ populations, even with the presence of susceptible plants, over $70 \%$ of the larvae did not reach the adult phase. In addition to antibiosis preventing a reduction in the photosynthetic capacity of the plants, it also reduced the pest population. Therefore, the introgression of these sources in commercial hybrids would reduce the need for chemical control, benefitting both humans and the environment.

\section{CONCLUSIONS}

Genetic variability exists among melon accessions in regard to leafminer resistance, and four new sources of resistance to leafminers were identified: 'CNPH 11-1072' and 'CNPH 11-1077' (by antixenosis), and 'CNPH 00-915(R)' and 'BAGMEL 56(R)' (by antibiosis).

Genetics and Molecular Research 16 (2): gmr16029561 


\title{
Conflicts of interest
}

The authors declare no conflict of interest.

\section{ACKNOWLEDGMENTS}

\author{
Tecnológico.
}

Research supported by Conselho Nacional de Desenvolvimento Científico e

\section{REFERENCES}

Albuquerque LB, Antonio RP, Nunes GHS, Medeiros RV, et al. (2015). Caracterização morfológica de fontes de resistência de meloeiro a Pseudoperonospora cubensis. Rev. Caatinga 28: 100-107. http://dx.doi.org/10.1590/1983$\underline{21252015 \mathrm{v} 28 \mathrm{n} 312 \mathrm{rc}}$

Aragão FAS (2011). Divergência genética de acessos e interação genótipo x ambiente de famílias de meloeiro. Doctoral thesis, Universidade Federal Rural do Semi-Árido. Available at http://www2.ufersa.edu.br/portal/view/uploads/ setores/82/Fernando\%20A\%20S\%20Arag\%C3\%A3o_\%20Doutorado_Tese_UFERSA.pdf.

Araújo EL, Fernandes DRR, Geremias LD, Menezes Netto AC, et al. (2007). Mosca-minadora associada à cultura do meloeiro no semiárido do Rio Grande do Norte. Rev. Caatinga 20: 210-212.

Araújo EL, Nogueira CHF, Menezes Netto AC and Bezerra CES (2013). Biological aspects of the leafminer Liriomyza sativae (Diptera: Agromyzidae) on melon (Cucumis melo L.). Cienc. Rural 43: 579-582. http://dx.doi.org/10.1590/ $\underline{\mathrm{S} 0103-84782013000400003}$

Basij M, Askarianzaeh A, Asgari S, Moharramipou S, et al. (2011). Evaluation of resistance of cucumber cultivars to the vegetable leafminer (Liriomyza sativae Blanchard) (Diptera: Agromyzidae) in greenhouse. Chil. J. Agric. Res. 1: 395-400. http://dx.doi.org/10.4067/S0718-58392011000300008

Borém A and Fritsche-Neto R (2012). Os desafios bióticos do melhoramento de plantas para alimentar o mundo. In: Melhoramento de planta para condições de estresses bióticos (Fritsche-Neto R and Borém A, eds.). Suprema, Visconde do Rio Branco, 9-24.

Borém A and Miranda GV (2013). Melhoramento de plantas. 6th edn. UFV, Viçosa.

Braga Sobrinho R, Guimarães JA, Lindembergue AMM, Chagas MCM, et al. (2003). Monitoramento de pragas na produção integrada do meloeiro. Documentos, 69. Embrapa Agroindústria Tropical, Fortaleza. Available at https:// www.embrapa.br/agroindustria-tropical/busca-de-publicacoes/-/publicacao/426324/monitoramento-de-pragas-naproducao-integrada-do-meloeiro. Accessed November 20, 2016.

Dogimont C (2011). Gene list for melon. Rep. Cucurbit Genet. Coop. 33: 1915-1933.

Dogimont C and Boissot N (2016). Insect resistance in melon and its modification by molecular breeding. In: Functional genomics and biotechnology in Solanaceae and Cucurbitaceae crops (Ezura H, Ariizumi T, Garcia-Mas J and Rose J, eds.). Springer, 199-219.

Dogimont C, Bordat D, Pitrat M and Pages C (1995). Characterization of resistance to Liriomyza trifolii (Burgess) in melon (Cucumis melo). Fruits 50: 449-452.

Dogimont C, Bordat D, Pages C, Boissot N, et al. (1999). One dominant gene conferring the resistance to the leafminer, Liriomyza trifolii (Burgess) Diptera: Agromyzidae in melon (Cucumis melo L.). Euphytica 105: 63-67. http://dx.doi. org/10.1023/A:1003436428847

Dogimont C, Bendahmane A, Chovelon V and Boissot N (2010). La résistance des plantes cultivées aux pucerons: bases génétiques et moléculaires et interaction avec les populations de pucerons. C. R. Biol. 333: 566-573. http://dx.doi. org/10.1016/j.crvi.2010.04.003

Ferreira ECB (2014). Estrutura genética de populações naturais de Liriomyza sativae (Diptera: Agromyzidae). Master's dissertation, Universidade Federal Rural de Pernambuco. Available at http://www.ppgea.ufrpe.br/?q=pt-br/ dissertacoes/estrutura-genetica-de-populacoes-naturais-de-liriomyza-sativae-blanchard-diptera.

Gallo D, Nakano O, Silveira Neto S, Carvalho RPL, et al. (2002). Manual de entomologia agrícola. FEALQ, Piracicaba.

Gesmallah AEE and Yousif MT (2004). Resistance in melons (Cucumis melo L.) to leafminers (Liriomyza spp.; Diptera: Agromyzidae). Gezira J. Agric. Sci. 2: 125-130.

Kennedy GG, Bohn GW, Stoner AK and Webb RE (1978). Leaf resistance in muskmelon. J. Am. Soc. Hortic. Sci. 103: $571-574$

Genetics and Molecular Research 16 (2): gmr16029561 
Lima TC, Geremias LD and Parra JRP (2009). Efeito da temperatura e umidade relativa do ar no desenvolvimento de Liriomyza sativae Blanchard (Diptera: Agromyzidae) em Vigna unguiculata. Neotrop. Entomol. 38: 727-733. http:// dx.doi.org/10.1590/S1519-566X2009000600004

MDIC (Ministério do Desenvolvimento, Indústria e Comércio Exterior) (2016). Sistema de análise das informações de comércio exterior, ALICEWEB. Available at http://aliceweb.mdic.gov.br/. Accessed November 15, 2016.

Morais AA and Pinheiro JB (2012). Melhoramento para resistência aos insetos-praga. In: Melhoramento de planta para condições de estresses bióticos (Fritsche-Neto R and Borém A, eds.). Suprema, Visconde do Rio Branco, 153-186.

Nunes GHS, Medeiros AC, Araújo EL, Nogueira CHF, et al. (2013). Resistência de acessos de meloeiro à moscaminadora Liriomyza spp. (Diptera: Agromyzidae). Rev. Bras. Frutic. 35: 746-754. http://dx.doi.org/10.1590/S010029452013000300011

Resende MDV and Duarte JB (2007). Precisão e controle de qualidade em experimentos de avaliação de cultivares. Pesq. Agr. Trop. 37: 182-194.

Sabato D, Esteras C, Grillo O, Picó B, et al. (2015). Seeds morpho-colourimetric analysis as complementary method to molecular characterization of melon diversity. Sci. Hortic. (Amsterdam) 192: 441-452. http://dx.doi.org/10.1016/j. $\underline{\text { scienta.2015.06.006 }}$

Genetics and Molecular Research 16 (2): gmr16029561 